\title{
NADLEŽNOST, NADLEŽNA TIJELA I POSTUPCI PREMA UREDBI (EU) BR. 650/2012 O NASLJEĐIVANJU
}

Dr. sc. Paula Poretti, viša asistentica

Pravni fakultet Sveučilišta u Osijeku

\author{
UDK: 347.65::061.1EU \\ Ur.: 18. ožujka 2016. \\ Pr.: 30. ožujka 2016. \\ Pregledni znanstveni rad
}

\begin{abstract}
Sažetak
$U$ radu se iznose novine koje u području nasljeđivanja donosi provedba Uredbe br. 650/2012 Europskog parlamenta i Vijeća od 4. srpnja 2012. o nadležnosti, mjerodavnom pravu, priznavanju i izvršavanju odluka i prihvaćanju i izvršavanju javnih isprava u nasljednim stvarima $i$ o uspostavi Europske potvrde o nasljeđivanju. Osobita se pažnja poklanja odredbama kojima je uređena nadležnost, tijela koja postupak provode kao i postupci koji će se provoditi u povodu Uredbe br. 650/2012 o nasljedivanju. U tom se smislu u prvom dijelu rada detaljno analiziraju odredbe koje vezano uz primjenu Uredbe br. 650/2012 o nasljeđivanju donose Provedbena uredba Komisije br. 1329/2014 od 9. prosinca 2014. o uspostavi obrazaca iz Uredbe br. 650/2012 Europskog parlamenta i Vijeća o nadležnosti, mjerodavnom pravu, priznavanju i izvršavanju odluka i prihvaćanju i izvršavanju javnih isprava $u$ nasljednim stvarima $i$ o uspostavi Europske potvrde o nasljeđivanju kao $i$ odredbe hrvatskog Zakona o provedbi Uredbe br. 650/2012 o nasljeđivanju. $U$ drugom dijelu rada analizira se predmet C404/14 Matoušková v. Republika Češka te se upućuje na poteškoće u pogledu razgraničenja područja primjene Uredbe (EZ) br. 2201/2003 te Uredbe br. 650/2012 o nasljeđivanju do kojih bi moglo doći u pojedinim predmetima s međunarodnim obilježjem.
\end{abstract}

Ključne riječi: nasljeđivanje, međunarodno obilježje, uredba o nasljeđivanju, javni bilježnik, postupak pred sudom, predmet C-404/14.

\section{UVOD}

Politika izgradnje Europske unije (dalje: EU) kao područja slobode, sigurnosti i pravde u kojem je osigurano slobodno kretanje osoba donošenjem mjera koje se odnose na pravosudnu suradnju u građanskim stvarima koje imaju prekogranične učinke, posebno kada su potrebne za ispravno funkcioniranje unutarnjeg tržišta u pozadini je odredbe čl. 81. st. 2. t. c Ugovora o funkcioniranju Europske unije ${ }^{1}$

1 Ugovor o funkcioniranju Europske unije (pročišćeni tekst), Službeni list C 326, 26.10.2012, str. 47-390. 
(dalje: UFEU). U tom je smislu poduzimanje koraka k ostvarenju načela uzajamnog priznavanja presuda i drugih odluka pravosudnih tijela kao kamena temeljca pravosudne suradnje u građanskim stvarima naglašeno na sastanku Europskog vijeća u Tampereu 15. i 16. listopada 1999. godine, a provedba zacrtana Zajedničkim programom mjera Komisije i Vijeća za provedbu načela uzajamnog priznavanja sudskih odluka u građanskim i trgovačkim stvarima donesenima 30. studenoga 2000. godine. Tim je programom naglašen značaj izrade isprave koja se odnosi na oporuke i nasljeđivanje, što je i konkretizirano Haškim programom: jačanje slobode, sigurnosti i pravde u Europskoj uniji koji je donesen na zasjedanju Europskog vijeća u Bruxellesu 4. i 5. studenoga 2004. godine. S obzirom na zaključak Europskog vijeća da se uzajamno priznanje treba proširiti na područja poput nasljeđivanja, koji je sadržan u novom višegodišnjem Stockholmskom programu - otvorena i sigurna Europa u službi i zaštiti građana donesenom na sastanku u Bruxellesu 10. i 11. prosinca 2009. godine, radi uklanjanja prepreka slobodnom kretanju osoba koje se trenutačno susreću s poteškoćama u ostvarivanju svojih prava u kontekstu nasljeđivanja u predmetima s međunarodnim obilježjem donesena je Uredba (EU) br. 650/2012 Europskog parlamenta i Vijeća od 4. srpnja 2012. o nadležnosti, mjerodavnom pravu, priznavanju i izvršavanju odluka i prihvaćanju i izvršavanju javnih isprava u nasljednim stvarima i o uspostavi Europske potvrde o nasljeđivanju ${ }^{2}$ (dalje: Uredba br. 650/2012 o nasljeđivanju). Uredba br. 650/2012 o nasljeđivanju primjenjuje se na sve građanskopravne aspekte nasljeđivanja, odnosno, sve oblike prijenosa imovine, prava i obveza zbog smrti, bilo dobrovoljnim prijenosom raspolaganjem imovinom zbog smrti, bilo prijenosom zakonskim nasljeđivanjem. $\mathrm{U}$ tu svrhu predviđene su odredbe o nadležnosti, mjerodavnom pravu, priznavanju ili, ako je to slučaj, prihvaćanju, izvršivosti i izvršavanju odluka, javnih isprava i sudskih nagodbi i o uspostavi Europske potvrde o nasljeđivanju. Budući da bi se europskom potvrdom o nasljeđivanju koja je predviđena Uredbom br. 650/2012 o nasljeđivanju trebalo olakšati rješavanje nasljeđivanja s prekograničnim obilježjem na način da bi njome nasljednici, legatari, izvršitelji oporuke ili upravitelji ostavinom trebali moći na pojednostavljen način dokazati svoj status odnosno prava i ovlasti u drugoj državi članici, Provedbenom uredbom Komisije (EU) br. 1329/2014 od 9. prosinca 2014. o uspostavi obrazaca iz Uredbe (EU) br. 650/2012 Europskog parlamenta i Vijeća o nadležnosti, mjerodavnom pravu, priznavanju i izvršavanju odluka i prihvaćanju i izvršavanju javnih isprava u nasljednim stvarima i o uspostavi Europske potvrde o nasljeđivanju ${ }^{3}$ uspostavljeni su obrasci kojima bi se trebala osigurati njezina

2 Uredba (EU) br. 650/2012 Europskog parlamenta i Vijeća od 4. srpnja 2012. o nadležnosti, mjerodavnom pravu, priznavanju i izvršavanju odluka i prihvaćanju i izvršavanju javnih isprava u nasljednim stvarima i o uspostavi Europske potvrde o nasljeđivanju, Službeni list EU L 201, 27.7.2012, str. 107.-134. Posebno izdanje na hrvatskom jeziku, poglavlje 19, vol. 010 str. $296-323$.

3 Provedbena uredba Komisije (EU) br. 1329/2014 od 9. prosinca 2014. o uspostavi obrazaca iz Uredbe (EU) br. 650/2012 Europskog parlamenta i Vijeća o nadležnosti, mjerodavnom pravu, priznavanju i izvršavanju odluka i prihvaćanju i izvršavanju javnih isprava u nasljednim stvarima i o uspostavi Europske potvrde o nasljeđivanju, Službeni list L 359, 16.12.2014, str. 30-84. 
ispravna, jednostavna i ujednačena primjena. Premda bi se Uredba br. 650/2012 o nasljeđivanju u hrvatskom pravu trebala izravno primjenjivati ${ }^{4}$, kao što je to slučaj $\mathrm{i}$ u drugim uredbama, i ovdje se na više mjesta upućuje na provedbene propise država članica, pa je u tom smislu donesen Zakon o provedbi Uredbe (EU) br. 650/2012 Europskog parlamenta i Vijeća od 4. srpnja 2012. o nadležnosti, mjerodavnom pravu, priznavanju i izvršavanju odluka i prihvaćanju i izvršavanju javnih isprava u nasljednim stvarima i o uspostavi Europske potvrde o nasljeđivanju ${ }^{5}$ (dalje: Zakon o provedbi Uredbe br. 650/2012 o nasljeđivanju). S aspekta postupovnog prava od osobitog su značaja odredbe Zakona o provedbi Uredbe br. 650/2012 o nasljeđivanju kojima je uređena nadležnost, nadležna tijela te postupci u povodu Uredbe br. 650/2012 o nasljeđivanju. Stoga, prvi će se dio rada baviti analizom normativnog okvira u dijelu koji određuje nadležnost, nadležna tijela i postupke, a u drugom dijelu rada prezentirat će se predmet C404/14 Matoušková v. Republika $\check{C}$ eška ${ }^{6}$ te s njim u vezi postavljeno pitanje Sudu pravde EU (dalje: CJEU) o tome treba li Uredba Vijeća (EZ) br. 2201/2003 od 27. studenoga 2003. o nadležnosti, priznavanju i izvršenju sudskih odluka u bračnim sporovima i u stvarima povezanim s roditeljskom odgovornošću, kojom se stavlja izvan snage Uredba (EZ) br. 1347/2000 (dalje: Uredba br. 2201/2003; Uredba Brisel II bis) tumačiti na način da je odobrenje sporazuma o raspodjeli nasljedstva koji za račun malodobnih potomaka sklopi skrbnik mjera koja se odnosi na izvršavanje roditeljske odgovornosti u smislu članka 1. st. 1. t. (b) Uredbe br. 2201/2003 i koja stoga potpada pod njezino područje primjene ili je takav postupak mjera koja se odnosi na nasljeđivanje u smislu članka 1. st. 3. t. (f) Uredbe br. 2201/2003, isključena iz njezina područja primjene, odnosno ulazi u područje primjene Uredbe br. 650/2012 o nasljeđivanju.

\section{NADLEŽNOST, NADLEŽNA TIJELA I POSTUPCI}

\subsection{Nadležnost}

Sukladno odredbi čl. 4. Uredbe br. 650/2012 o nasljeđivanju opća nadležnost za odlučivanje o nasljeđivanju u cijelosti pripada sudovima države članice u kojoj je umrli imao svoje uobičajeno boravište u trenutku smrti. Države članice u smislu Preambule (82. i 83.) Uredbe br. 650/2012 o nasljeđivanju su sve države osim Ujedinjenog Kraljevstva, Irske i Danske.

4 Usporedi čl. 288. st. 2. UFEU.

5 Zakon o provedbi Uredbe (EU) br. 650/2012 Europskog parlamenta i Vijeća od 4. srpnja 2012. o nadležnosti, mjerodavnom pravu, priznavanju i izvršavanju odluka i prihvaćanju i izvršavanju javnih isprava u nasljednim stvarima i o uspostavi Europske potvrde o nasljeđivanju, NN br. 152/14.

6 Predmet C404/14 Matoušková v. Republika Češka, ECLI:EU:C:2015:653.

7 Uredba Vijeća (EZ) br. 2201/2003 od 27. studenoga 2003. o nadležnosti, priznavanju i izvršenju sudskih odluka u bračnim sporovima i u stvarima povezanim s roditeljskom odgovornošću, kojom se stavlja izvan snage Uredba (EZ) br. 1347/2000, Službeni list L 338 , 23/12/2003 P. $0001-0029$. 
Uredba br. 650/2012 o nasljeđivanju vodi računa o razlikama u uređenju pitanja nasljeđivanja u nacionalnom pravu država članica, osobito u pogledu ovlaštenja tijela nadležnih za postupanje. Stoga se pojam ,sud“ kao tijelo nadležno za postupanje u pitanjima nasljeđivanja ima široko tumačiti kako bi se uz sudove obuhvatili i javni bilježnici, registarski uredi te drugi pravni stručnjaci koji u državama članicama odlučuju o pitanjima nasljeđivanja (arg. ex čl. 3. st. 2., Preambula 20). Budući da se pri određenju pojma „sud“ javne bilježnike, koji u određenim pitanjima nasljeđivanja vrše sudske funkcije ili u nekim državama vrše sudske funkcije kod nasljeđivanja na temelju prenesenih ovlasti od suda izjednačilo sa sudovima, opravdano se postavlja pitanje mogu li javni bilježnici sukladno odredbi čl. 267. st. 2. UFEU (bivši čl. 234. UEZ) podnijeti zahtjev za prethodnu odluku CJEU, ako se u postupku prilikom donošenja odluke pojavi pitanje vezano uz tumačenje europskog zakonodavstva. U ranijim je odlukama CJEU vezano uz to pitanje sugerirao da se ima preispitati udovoljavaju li javni bilježnici kriterijima utemeljenosti nadležnosti u odredbama zakona, stalnosti, nevisnosti, primjene zakona i djelovanja odluke inter partes te pretpostavkama koje predviđa odredba čl. 234. UEZ. ${ }^{8}$ Uzimajući navedeno u obzir moguće je zaključiti da bi javni bilježnici kao sudski povjerenici u smislu odredaba hrvatskog prava bili ovlašteni podnijeti zahtjev za prethodnu odluku CJEU, što proizlazi iz odredbe čl. 176. st. 1. i 4. Zakona o nasljeđivanju ${ }^{9}$ (dalje: ZN). ${ }^{10}$ U okviru predmeta C404/14 Matoušková v. Republika Češka nezavisna odvjetnica Kokott upozorila je na još jedan aspekt, vezan uz prirodu postupka, koji može dovesti u pitanje dopuštenost zahtjeva koji CJEU upućuje javni bilježnik koji postupa u ostavinskom postupku. Naime, postupak u okviru kojega se pojavilo pitanje radi kojega je upućen zahtjev za prethodnu odluku je ostavinski postupak koji se prema češkom pravu vodi prema pravilima izvanparničnog postupka. Premda se prema shvaćanju nezavisne odvjetnice Kokott radi o tzv. postupku ,dobrovoljne nadležnosti“, okolnost da se zbog odbijanja Općinskog suda u Brnu (Městsky soud v Brně) da se proglasi nenadležnim i odbijanja upućivanja predmeta Vrhovnom sudu (Nejvyššíjem soudu) pojavio spor u postupku opravdava donošenje odluke o dopuštenosti zahtjeva za prethodnu odluku koji je upućen. ${ }^{11}$

Stoga bi, argumentum per analogiam trebalo zaključiti da bi i zahtjev za prethodnu odluku hrvatskoga javnog bilježnika ovlaštenog da vodi ostavinski postupak koji je sukladno odredbi čl. 175. ZN predviđen kao izvanparnični,

8 Predmet C-96/04 Standesamt Stadt Niebül. Usporedi predmet C-54/96 Dorsch Consult [1997] ECR I-4961.

9 Zakon o nasljeđivanju, $\mathrm{NN}$ br. 48/03, 163/03, 35/05, 127/13, 33/15.

10 Za njemačko pravo izveden je istovjetan zaključak. Usporedi, Dutta, A., Novo međunarodno nasljedno pravo Evropske unije - prvo čitanje Uredbe o nasljednom pravu, Nova pravna revija, Sarajevo, 2/2013, str. 9-22, str. 10.

11 Usporedi Mišljenje nezavisne odvjetnice Juliene Kokott od 25. lipnja 2015. u predmetu C404/14 Matoušková v. Republika Češka, ECLI:EU:C:2015:428, t. 25-27. 
nesporni, odnosno postupak tzv. „dobrovoljne sudbenosti“"12 (jurisdictio non contentiosa) također bio dopušten ako bi bio upućen u situaciji u kojoj zahtjevu javnoga bilježnika nije udovoljeno te je u pogledu toga nastao spor u postupku.

Uobičajeno boravište umrlog u vrijeme smrti sukladno odredbi čl. 4. Uredbe br. 650/2012 o nasljeđivanju kriterij je pomoću kojega se utvrđuje nadležnost suda za rješavanje nasljednih stvari s prekograničnim elementom. Pravila nacionalnog prava država članica primjenjuju se za utvrđivanje nadležnosti za rješavanje domaćih nasljednih stvari, s obzirom na to da odredba čl. 2. Uredbe br. 650/2012 o nasljeđivanju izrijekom predviđa da Uredba ne utječe na nadležnost tijela država članica za rješavanje o nasljednim stvarima. Pritom, iz tumačenja Uredbe br. 650/2012 o nasljeđivanju nije jasno kako se određuje prekogranični element nasljednih stvari. Ako se slijedi shvaćanje iz pravne literature, potrebno je uzeti u obzir četiri određujuća elementa, sudove odnosno nadležna tijela, umrlu osobu, nasljedstvo te nasljednike. ${ }^{13}$

Ako se pođe od prakse CJEU vezano uz interpretaciju odredaba svih pravnih akata koji se temelje na odredbi čl. 81. UFEU te uzmu u obzir shvaćanja pravnih teoretičara, odredbe Uredbe br. 650/2012 o nasljeđivanju se imaju tumačiti autonomno, odnosno na način da se odredbi ne učitava onaj sadržaj i smisao koji ona ima prema nacionalnom pravu nego imajući u vidu njezinu funkciju u postizanju onih zadaća radi kojih je donesen pojedini instrument europskog zakonodavstva. ${ }^{14}$ Tako je i izbor uobičajenog boravišta umrlog u trenutku smrti kao opće poveznice za potrebe utvrđivanja nadležnosti potrebno promatrati u kontekstu cilja kojega se usvajanjem Uredbe br. 650/2012 o nasljeđivanju željelo ostvariti odnosno uklanjanja prepreka slobodnom kretanju osoba koje se trenutačno susreću s poteškoćama u ostvarivanju svojih prava u kontekstu nasljeđivanja koje ima prekogranične implikacije. Naime, napuštanje domicila (lex domicilii) i državljanstva (lex patriae), kao široko primjenjivanih kriterija unutar nacionalnih pravila o sukobu zakona i sukobu nadležnosti, podjednako, pravnih sustava common law i kontinentalnoeuropskog pravnog kruga dio je trenda imanentnog na EU razini, osobito izražen na području pravosudne suradnje u građanskim stvarima. ${ }^{15}$ Vezan je ponajprije uz procjenu da kriterij uobičajnog boravišta u većoj mjeri odgovara primjeni unutar EU, s obzirom na broj građana koji žive izvan države članice čiji

12 O pojmu dobrovoljne sudbenosti vidi Triva, S. i Dika, M, Građansko parnično procesno pravo, Zagreb, Narodne novine, 2004, str. 53. Usporedi Maganić, A. i dr., Izvanparnično pravo: s komentarom, primjerima obrazaca za praktičnu primjenu, sudskom praksom, bilješkama i zbirkom propisa, Zagreb, Vizura, 2015., 53-91.

13 Drličková, K. i Rohová, I., Habitual Residence as a Single Connecting Factor Under the Succession Regulation, u: Scientific Cooperations (ur.), Scientific Cooperations Workshops on Social Sciences, Ankara, Scientific Cooperations, 2015., str. 371-381., na str. 374.

14 Usporedi C-443/03 Leffler; C-386/05 Color Drack. Tako Dutta, A. op.cit., str. 9.

15 Usporedi Sturm, F. i Sturm, G., Das Europäische Nachlasszeugnis: Zum Vorschlag der Kommission vom 14. Oktober 2009., Zagreb, Zbornik Pravnog fakulteta u Zagrebu, vol. 62, 1-2/2012, str. 331-358, na str. 340. Usporedi Atallah, M., The Last Habitual Residence of the Deceased as the Principal Connecting Factor in the Context of the Succession Regulation (650/2012), Baltic Journal of European Studies, vol. 5, 2/2015., str. 130-146., str. 135. 
su državljani. ${ }^{16}$ Uobičajeno boravište, s obzirom na to da nije pravno definiran pojam, moguće je procjenjivati prema okolnostima svakog pojedinačnog slučaja te $u$ tom smislu olakšava detekciju najprikladnijeg foruma za rješavanje spora te primjenu mjerodavnog prava. Uz to, pogodan je za slučajeve u kojima osobe imaju državljanstvo više država članica kao i slučajeve kada je riječ o osobama bez državljanstva, odnosno apatridima. ${ }^{17}$

U svrhu pojednostavljenja postupanja, osim za utvrđivanje nadležnosti, Uredba br. 650/2012 o nasljeđivanju predviđa kriterij uobičajenog boravišta za utvrđivanje mjerodavnog prava, uvodeći ga tako kao jedinstveni kriterij. Uobičajeno boravište najčešće se može uzeti i kao mjesto na kojemu se nalazi imovina umrlog ili barem njezin pretežiti dio. U tom je smislu za pretpostaviti da je europski zakonodavac uzeo u obzir iskustva dijela država članica koje za utvrđivanje prava mjerodavnog za nasljeđivanje primjenjuju kriterij mjesta gdje se nalazi imovina umrlog. $\mathrm{O}$ prednostima i nedostacima izbora uobičajnog boravišta kao kriterija za utvrđivanje mjerodavnog prava detaljnije će se govoriti u nastavku.

Vezano uz procjenu uobičajenog boravišta, iz Preambule (23) Uredbe br. $650 / 2012$ o nasljeđivanju proizlazi da će tijelo ${ }^{18}$ koje se bavi nasljeđivanjem biti u mogućnosti izvršiti ukupnu procjenu životnih okolnosti umrlog tijekom posljednjih godina njegovog života i u trenutku smrti, uzimajući u obzir sve relevantne činjenične elemente, posebno trajanje i stalnost prisutnosti umrlog u dotičnoj državi te uvjete i razloge za tu prisutnost. Na taj način utvrđeno uobičajeno boravište trebalo bi imati blisku i stabilnu vezu s dotičnom državom, uzimajući u obzir konkretne ciljeve Uredbe br. 650/2012 o nasljeđivanju. Očigledno, pri oblikovanja smjernica pomoću kojih se ima utvrđivati uobičajeno boravište imalo se u vidu presudu CJEU u predmetu C-523/07 $\mathrm{A}^{19}$ u kojoj je jasno podcrtano kako uobičajeno boravište nije moguće utvrditi isključivo na temelju fizičke prisutnosti osobe te je

16 Za razliku od Uredbe (EU) br. 1215/2012 Europskog parlamenta i Vijeća od 12. prosinca 2012. o nadležnosti, priznavanju i izvršenju sudskih odluka u građanskim i trgovačkim stvarima (preinačena), Službeni list EU, L 351, 20.12.2012, str. 1-32. (dalje: Uredba (EU) br. 1215/2012; Uredba Brisel I bis) koja još uvijek zadržava kriterij domicila pri određivanju nadležnosti, kriterij uobičajenog boravišta od početne primjene u okviru Haške konferencije o međunarodnom privatnom pravu (dalje: Haška konferencija) proširio se i na Uredbu br. 2201/2003, Uredbu (EZ) br. 593/2008 Europskog parlamenta i Vijeća od 17. lipnja 2008. o pravu koje se primjenjuje na ugovorne obveze, Službeni list EU L 177, 4.7.2008., str. 109119. (dalje: Uredba br. 593/2008; Uredba Rim I) te Uredbu Vijeća (EZ) br. 4/2009 od 18. prosinca 2008. o nadležnosti, mjerodavnom pravu, priznavanju i izvršenju sudskih odluka te suradnji u stvarima koje se odnose na obvezu uzdržavanja, Službeni list 7, 10.1.2009., str. 1-79. (dalje: Uredba br. 4/2009; Uredba o uzdržavanju).

17 Lamont, R. Habitual Residence and Brussels II bis: Developing Concepts for European Private International Family Law. Journal of Private International Law, vol. 3, 2/2007, str. 261-281., 263.

18 Nije posve jasno zbog čega se, primjerice, u Preambuli 23, 25 i 27 koristi pojam „tijelo“, a u Preambuli 26 i na drugim mjestima pojam ,sud“, premda se govori o „tijelima koja se bave nasljeđivanjem“ za koja je odredbom čl. 3. st. 2. Uredbe br. 650/2012 o nasljeđivanju predviđeno da su obuhvaćena pojmom ,sud“.

19 Predmet C-523/07 A, ECLI:EU:C:2009:225. 
u tom smislu ponuđeno nekoliko kriterija, poput trajanja boravka u državi članici, uvjeta i razloga boravka, poznavanja jezika i drugog.

Istovremeno, Uredba br. 650/2012 o nasljeđivanju vodi računa i o situacijama u kojima, unatoč predviđenim smjernicama, nije moguće bez poteškoća utvrditi uobičajeno boravište. Tako u Preambuli (24) za slučaj da je umrli zbog profesionalnih ili ekonomskih razloga otišao živjeti u inozemstvo kako bi tamo radio, ponekad dugo vremena, ali je zadržao blisku i stabilnu vezu sa svojom državom podrijetla, predviđeno je da bi se moglo i dalje smatrati, ovisno o okolnostima slučaja, da je umrli imao svoje uobičajeno boravište u svojoj državi podrijetla u kojoj je bilo središte interesa njegove obitelji i njegov društveni život. Drugi se primjer složenog slučaja tiče situacije u kojoj je umrli živio u nekoliko država naizmjence ili je putovao iz jedne države u drugu, a da se nije stalno nastanio u bilo kojoj od njih. Sukladno Preambuli (24) ako je umrli bio državljanin jedne od tih država ili ako je imao svu svoju glavnu imovinu u jednoj od tih država, državljanstvo ili mjesto te imovine mogli bi biti poseban čimbenik u ukupnoj procjeni svih činjeničnih okolnosti.

Unatoč tome što se u okviru Preambule Uredbe br. 650/2012 o nasljeđivanju nastojalo razriješiti potencijalne nejasnoće u interpretaciji kriterija uobičajenog boravišta, i dalje je potrebno uz prednosti, u usporedbi s primjenom kriterija domicila i državljanstva, imati na umu moguće nedostatke primjene kriterija uobičajenog boravišta, osobito ako se uzme u obzir neujednačenost u njegovu tumačenju država članica. Iz perspektive njemačkih pravnih teoretičara u čijem je pravnom sustavu uvriježena primjena kriterija domicila prilikom određivanju nadležnosti u prekograničnim sporovima u nasljednim stvarima, primjena kriterija uobičajenog boravišta suviše je nejasna te sudovima dodjeljuje značajan prostor za diskreciju odlučivanju. ${ }^{20} \mathrm{Uz}$ to, omogućuje oporučnom ostavitelju da namjerno promijeni boravište kako bi izbjegao primjenu prava koje bi trebalo biti primijenjeno. $U$ isto vrijeme, pravo mjerodavno za nasljeđivanje kao pravo države uobičajenog boravišta ne mora nužno predstavljati pravo države s kojom je umrli bio u najvećoj mjeri povezan, čak suprotno može biti riječ o pravu kojega umrli nije niti poznavao. ${ }^{21}$

Nekoliko je argumenata moguće iznijeti kao odgovor na kritiku njemačkih teoretičara. U prvom redu, već spomenutu okolnost da se kriterij uobičajenog boravišta pri određivanju nadležnosti suda primjenjuje i u drugim europskim instrumentima na području pravosudne suradnje u građanskim stvarima. Uz to, okolnost da uobičajeno boravište pretpostavlja određeni stupanj trajnije, kontinuirane povezanosti između umrlog i boravišta odnosno područja na kojemu se nalazi sud. Konačno, predviđeno osiguranje od zlouporabe kriterija uobičajenog boravišta iz Preambule (25) Uredbe br. 650/2012 o nasljeđivanju na način da se

20 Usporedi Dutta, A., op. cit. str. 10. Vidi još Kränzle, M., Heimat als Rechtsbegriff? Eine Untersuchung zu Domicile und gewöhnlichem Aufenthalt im Lichte der EUErbrechtsverordnung, Mohr Siebeck, 2014., str. 271.

21 Usporedi Drličková, K. i Rohová, I., str. 378. 
upozorava da se najbližoj vezi ne bi trebalo pribjegavati kao supsidijarnoj poveznici svaki put kada se utvrđivanje uobičajenog boravišta umrlog u vrijeme smrti pokaže složenim. ${ }^{22}$

Uz opće pravilo, odredbom čl. 5. Uredbe br. 650/2012 o nasljeđivanju predviđeno je pravilo o prorogaciji nadležnosti sukladno kojemu ako je umrli za uređenje svojeg nasljeđivanja u skladu s čl. 22. Uredbe br. 650/2012 izabrao pravo države članice čiji je državljanin, stranke na koje se to odnosi mogu se sporazumjeti da sud ili sudovi te države članice imaju isključivu nadležnost odlučivati o svim nasljednim stvarima. Iz toga proizlazi da se opće pravilo o nadležnosti suda uobičajenog boravišta umrlog neće primjenjivati samo ako se s izborom umrlog slože stranke u naknadnom postupku o nasljeđivanju te se pri tome sukladno odredbi čl. 5. st. 2. Uredbe br. 650/2012 o nadležnosti o prorogaciji sporazume u pisanom obliku, sporazum datiraju i potpišu, a jednakovrijedan pisani oblik jest i svako priopćenje elektroničkim sredstvima koja osiguravaju trajni zapis sporazuma. Pritom, trebalo bi uzeti da i priopćenja elektroničkim sredstvima trebaju zadovoljavati propisanu formu odnosno biti potpisana elektroničkim potpisom kako bi ih se smatralo jednakovrijednima. ${ }^{23}$ Uredba br. 650/2012 o nadležnosti u pristupu slijedi ostale europske dokumente ${ }^{24}$ koji strankama ostavljaju mogućnost izbora nadležnog suda. Istovremeno, osigurava da se primjenom ovog pravila ne narušava temeljna ideja prema kojoj sud države uobičajenog boravišta umrlog neće biti u poziciji da primjenjuje strano odnosno pravo druge države članice. Bitno je za napomenuti da argumentum a contrario iz odredbe čl. 5. st. 1. Uredbe br. 650/2012 o nasljeđivanju proizlazi da je izbor mjerodavnog prava, od strane umrlog ograničen na pravo država članica te da izbor prava tzv. treće države neće biti od utjecaja na nadležnost suda. Hoće li i u kojoj mjeri odredba čl. 5. Uredbe br. 650/2012 o nasljeđivanju naići na primjenu u praksi ovisi u prvom redu o dostupnosti stranaka na početku postupka, ali i njihovoj spremnosti da postignu sporazum o prorogaciji. ${ }^{25}$

Iz perspektive njemačke pravne teorije autonomija stranaka prilikom sporazumijevanja o nadležnosti u okviru Uredbe br. 650/2012 o nasljeđivanju neprimjereno je ograničena idejom da prorogacija nadležnosti, kako to predviđa odredba čl. 5., treba poslužiti za onemogućavanje primjene stranog prava. Stoga, sugerira se šire tumačenje odredbe čl. 5. (i odredaba koje slijede) čime bi se odstupilo od ograničenja koje postavlja odredba čl. 22. Uredbe br. 650/2012 o nasljeđivanju, a ako je umrli za života učinio izbor isključivo u pogledu dopuštenosti i materijalnopravne valjanosti raspolaganja u slučaju smrti sukladno odredbi čl. 24 .

22 Ibid, str. 378-379.

23 Usporedi Popescu, D. A., Guide on international private law on succession matters, Alina Chițeală - Onești: Magic Print, 2014, str. 34.

24 Usporedi mogućnosti izbora nadležnosti suda u drugim europskim instrumentima: odredba čl. 23. i 25. Uredbe br. 1215/2012 te odredba čl. 12 Uredbe br. 2201/2003.

25 Hess, B., Mariottini, C. i Camara, C., Regulation (EC) n. 650/2012 of July 2012 on jurisdiction, applicable law, recognition and enforcement of authentic instruments in matters of succession and on the creation of a European Certificate of Succession, Brussels, European Parliament, 2012., str. 11. 
st. 2. ili prema čl. 25. st. 3. Uredbe br. 650/2012 o nasljeđivanju, i odstupanje od primjene kriterija uobičajenog boravišta. ${ }^{26}$

U slučaju da je postupak započeo pred sudom nadležnim prema uobičajenom boravištu umrlog (arg. ex čl. 4.) ili sudom nadležnim sukladno pravilu o supsidijarnoj nadležnosti (arg. ex čl. 10.), a umrli je za uređenje svog nasljeđivanja izabrao pravo države članice u skladu s odredbom čl. 22., sud može odbiti nadležnost na zahtjev jedne od stranaka, ako ocijeni da su sudovi države članice izabranog prava u boljem položaju odlučivati o nasljeđivanju, uzimajući u obzir praktične okolnosti nasljeđivanja, poput uobičajenog boravišta stranaka i mjesta gdje se imovina nalazi (arg. ex čl. 6. t. a), a mora odbiti nadležnost ako su se stranke, sukladno pravilu o prorogaciji iz odredbe čl. 5., u postupku sporazumjele o prenošenju nadležnosti na sud ili sudove države članice izabranog prava (arg. ex čl. 6. t. b). Pravilom kojim se omogućuje sudu da odbije nadležnost u slučaju da je umrli izabrao pravo za uređenje svog nasljeđivanja ide se za tim da se održi temeljno pravilo o usklađenosti odnosno podudarnosti nadležnog suda i mjerodavnog prava. ${ }^{27}$ Ono je osobito prikladno za situacije gdje umrli nije duže vrijeme živio u državi članici različitoj od države članice čiji je državljanin, a uz to vjerojatno je da se nasljednici umrlog nalaze u toj državi članici te da se nisu sporazumjeli o prorogaciji nadležnosti sukladno odredbi čl. 5. Uredbe br. 650/2012. No, istovremeno ne vodi računa o situacijama gdje je umrli kratko vrijeme živio u državi članici različitoj od države članice čiji je državljanin, a prije smrti nije izabrao pravo za uređenje svog nasljeđivanja, zbog čega će nasljednici umrlog koji žive u državi članici čiji je državljanin umrli postupak voditi u državi članici posljednjeg uobičajenog boravišta umrlog. U tom smislu, opravdana je primjedba da je izostanak odredbe o mogućnosti izravne suradnje između sudaca suda države članice uobičajenog boravišta i suda države članice čiji je državljanin umrli osjetan nedostatak jer bi se time značajno olakšala pravilna primjena odredaba čl. 6. i 8 . Uredbe br. 650/2012. ${ }^{28}$

U slučaju da je posljednje uobičajeno boravište umrlog bilo izvan država članica odnosno u tzv. trećoj državi, odredbom čl. 10. Uredbe br. 650/2012 o nasljeđivanju predviđena je mogućnost uspostavljanja supsidijarne nadležnosti suda države članice u kojoj se nalazi imovina ostavine, ako je umrli imao državljanstvo te države članice u trenutku smrti (arg. ex čl. 10. st. 1. t. a) ili ako je umrli imao svoje prethodno uobičajeno boravište u toj državi članici, pod uvjetom da u trenutku

26 Dutta, A., op. cit., str. 12. Suprotno tome, Janzen, U., Die EU-Erbrechtsverordnung, Deutsche Notar-Zeitschrift, 7/2012, str. 484-493, str. 491.

27 Pravilo koje omogućuje da sud odbije nadležnost zbog procjene da je drugi sud prikladniji za vođenje postupka (forum non conveniens) imanentno je pravnim sustavima koji pripadaju common law pravnom krugu. Ipak, postupno pravilo svoju primjenu nalazi i u europskom zakonodavstvu iz područja pravosudne suradnje u građanskim stvarima. Tako je odredbu u kojoj se primjenjuje pravilo forum non conveniens moguće pronaći i u odredbi čl. 15. Uredbe br. 2201/2003. Usporedi Hess, B., Mariottini, C. i Camara, C, loc. cit.

28 Usporedi Hess, B., Jayme, E. i Pfeiffer, T., Opinion on the proposal for a European regulation on succession law - Version 2009/157 (COD) of 16 January 2012, Brussels, European Parliament, 2012., str. 23. 
kada je postupak pokrenut pred sudom nije proteklo više od pet godina od promjene tog uobičajenog boravišta (arg. ex čl. 10. st. 1. t. b). Ako se nadležnost suda u državi članici ne može uspostaviti sukladno odredbi čl. 10. st. 1. Uredbe br. 650/2012 o nasljeđivanju, sudovi države članice u kojoj se nalazi imovina ostavine svejedno imaju nadležnost odlučivati o toj imovini. Očigledno, kako bi se omogućilo da se za nasljednike umrlog postupak odlučivanja o nasljeđivanju provede u jednoj od država članica umjesto u tzv. trećoj državi i sukladno režimu Uredbe br. 650/2012 o nasljeđivanju, odstupa se od kriterija uobičajenog boravišta za kojega se smatra da osigurava najbližu vezu između umrlog, suda i mjerodavnog prava te se kao relevantni kriterij za uspostavljanje nadležnosti uzima područje države članice gdje se nalazi imovina. Naime, iz dikcije odredbe jasno proizlazi da neovisno o tome što je umrli imao državljanstvo ili prethodno uobičajeno boravište u državi članici, nadležnost se neće uspostaviti ako na području te države članice nema imovine umrlog, bez obzira je li riječ o pokretnoj ili nepokretnoj imovini. Tome u prilog govori i okolnost da prilikom utvrđivanja nadležnosti, prednost se daje sudu države članice čije je državljanstvo umrli imao u trenutku smrti, a tek ako to nije slučaj. Nadležnost se uspostavlja prema prethodnom uobičajenom boravištu umrlog, uz uvjet da u trenutku kada je postupak pokrenut pred sudom nije proteklo više od pet godina od promjene tog uobičajenog boravišta ili ako za to nema uvjeta, prema mjestu gdje se nalazi imovina. No, dok u slučaju da se nadležnost uspostavlja prema državljanstvu ili prethodnom uobičajenom boravištu umrlog sudovi države članice u kojoj se nalazi imovina ostavine imaju nadležnost odlučivati o nasljeđivanju u cijelosti (tzv. potpuna nadležnost). Ako se uspostavlja prema mjestu gdje se nalazi imovina ostavine sudovi te države članice imaju nadležnost odlučivati isključivo o toj imovini, a ne o cjelokupnoj imovini ostavine (tzv. ograničena nadležnost) (arg. ex čl. 10.). ${ }^{29}$

U slučaju da je umrli u trenutku smrti imao državljanstvo nekoliko država članica bit će potrebno utvrditi koji će sud biti nadležan za odlučivanje o ostavini, imajući u vidu praksu $\mathrm{CJEU}^{30}$. Ako se ocijeni da više sudova udovoljava zahtjevima postavljenima odredbom čl. 10. st. 1. pa stranke istovremeno pokrenu postupak pred dva ili više sudova, odredba čl. 17. Uredbe br. 650/2012 o nasljeđivanju predviđa da će svi sudovi, osim onog pred kojim je najprije započet postupak zastati s postupcima, po službenoj dužnosti, sve dok se ne utvrdi nadležnost suda koji je prvi započeo postupak.

Konačno, Uredba br. 650/2012 o nasljeđivanju predviđa pravilo o forum necessitatis kojim omogućuje da čak i u slučaju da se nadležnost sudova država članica ne može uspostaviti ni prema jednom od pravila Uredbe, sudovi države članice, u iznimnim slučajevima, mogu odlučivati o nasljeđivanju ako u trećoj državi s kojom je slučaj usko povezan postupak nije moguće pokrenuti ili provesti

29 O tzv. potpunoj i ograničenoj nadležnosti u smislu odredbe čl. 10. Uredbe br. 650/2012 o nasljeđivanju vidi više Dutta, A., loc. cit., str. 11. Usporedi Adolphsen, Jens, Europäisches Zivilverfahrensrecht, Springer Verlag, 2015., str. 309.

30 Vidi više predmet C-168/08, Hadadi, ECLI:EU:C:2009:474. 
u razumnim okvirima ili postupak u trećoj državi nije moguć (arg. ex čl. 11. st. 1.). Budući da slučaj mora u dovoljnoj mjeri biti povezan s državom članicom suda pred kojim je pokrenut postupak za pretpostaviti je da bi se i ovdje kao relevantan kriterij za uspostavljanje nadležnosti moglo uzeti državljanstvo ili prethodno uobičajeno boravište umrlog.

Ako se sukladno Uredbi br. 650/2012 o nasljeđivanju uspostavi nadležnost suda RH, mjesna nadležnost općinskog suda za provođenje ostavinskog postupka odredit će se primjenom odredaba ZN (arg. ex čl. 3. Zakona o provedbi Uredbe br. 650/2012 o nasljeđivanju). Iz toga slijedi da će mjesno nadležan biti sud na čijem je području ostavitelj u vrijeme smrti imao prebivalište (ostavinski sud) ili, ako ostavitelj u vrijeme smrti nije imao prebivalište u RH, sud na čijem je području ostavitelj u to vrijeme imao boravište (arg. ex čl. 177. st. 1. i 2. ZN). Ako ostavitelj $\mathrm{u}$ vrijeme smrti nije imao prebivalište ni boravište $\mathrm{u} \mathrm{RH}$, mjesno će biti nadležan sud na čijem se području nalazi pretežiti dio njegove ostavine u RH (arg. ex čl. 177. st. 3. ZN). U slučaju da se nijedan dio ostavine ne nalazi u RH mjesno je nadležan sud prema mjestu gdje je ostavitelj upisan u knjigu državljana (arg. ex čl. 177. st. 4. $\mathrm{ZN})$

U usporedbi s kriterijem domicila, nedvojbeno primjena kriterija uobičajenog boravišta postavlja više zahtjeve naspram suda da na temelju procjene svakog pojedinačnog slučaja odredi nadležnost. ${ }^{31}$

Nomotehničko rješenje predviđeno Uredbom br. 650/2012 o nasljeđivanju vodi računa da bi osnovno pravilo trebalo osigurati da nasljeđivanje uređuje predvidivo pravo koje je blisko povezano ${ }^{32}$ te u tom smislu usklađuje nadležni sud i mjerodavno pravo na način da bi, osim u slučajevima ako je umrli za pravo koje će uređivati njegovo nasljeđivanje odabrao pravo države članice čiji je bio državljanin, tijelo koje se bavi nasljeđivanjem trebalo bi primjenjivati vlastito pravo (arg. ex Preambula 27). Tako je odredbom čl. 21. st. 1. Uredbe br. 650/2012 o nasljeđivanju predviđeno da osim ako je drukčije predviđeno ovom Uredbom, pravo mjerodavno za nasljeđivanje u cijelosti pravo je države u kojoj je umrli imao svoje uobičajeno boravište u trenutku smrti.

U prilog ovako postavljenog rješenja uz razloge ekonomičnosti u postupanju, predvidivosti te pravne sigurnosti govori i izbjegavanje mogućnosti pribjegavanja primjeni odredbe čl. 35. Uredbe br. 650/2012 prema kojoj se djelovanje odredbe prava bilo koje države određene Uredbom može otkloniti ako bi to bilo očigledno nespojivo s javnim poretkom (ordre public) države suda. ${ }^{33}$

31 Usporedi Drličková, K. i Rohová, I., loc.cit.

32 Vidi Preambula (37) Uredbe br. 650/2012 o nasljeđivanju.

33 Ovo zakonodavno rješenje doprinosi olakšavanju pristupa sudu, naglašavajući jednostavnost i predvidljivost koje su temeljni ciljevi Uredbe br. 650/2012 o nasljeđivanju. Okolnost da tijelo koje se bavi nasljeđivanjem primjenjuje vlastito pravo postupke čini jednostavnijim za vođenje, kratkotrajnijim i jeftinijim. Utvrđivanje i primjena stranog prava doprinosi odugovlačenju postupaka i povećava troškove. Hess, B., Mariottini, C. i Camara, C., op. cit., str. 14. 
Kao izuzetak od općeg pravila, predviđeno je da ako je u trenutku smrti umrli bio očigledno bliže povezan s državom koja nije država čije bi pravo bilo mjerodavno kao pravo države u kojoj je umrli imao svoje uobičajeno boravište, pravo mjerodavno za nasljeđivanje je pravo te druge države (arg. ex čl. 21. st. 2.). Odstupanje od općeg pravila ovdje služi kako bi se osiguralo da se o nasljeđivanju odlučuje uz primjenu prava koje je najprikladnije, s obzirom na to da u određenim slučajevima primjena prava uobičajenog boravišta ne osigurava najbližu vezu umrlog i prava koje se ima primijeniti. To je osobito izraženo u onim slučajevima u kojima se umrli preselio u državu članicu neposredno prije smrti, premda je dugi niz godina živio u drugoj državi članici. ${ }^{34}$

Pravo koje će u cijelosti urediti nasljedstvo osobe može sukladno njezinom izboru biti pravo države čiji je državljanin u trenutku izbora ili u trenutku smrti (arg. ex čl. 22. st. 1.). Premda to ne mora nužno biti pravilo, za pretpostaviti je da će se u određenom broju slučajeva pravo države čiji je osoba državljanin u trenutku izbora biti istovjetno pravu države čiji je osoba državljanin u trenutku smrti. Premda se načelno poštuje autonomija volje osobe da prije smrti izabere pravo koje će u cijelosti urediti njezino nasljeđivanje, i tako odstupa od primjene općeg pravila o mjerodavnom pravu, izbor je ipak ograničen na pravo države čiji je osoba državljanin. Prema Preambuli (38) na taj način osim što se osigurava veza između umrlog i izabranog prava, ujedno se izbjegava da se pravo izabere s namjerom da se ne ostvare legitimna očekivanja osoba koja imaju pravo na nužni dio. U pravnoj literaturi to je protumačeno na način da se time omogućilo ostavitelju da izabere pravo države članice čiji je državljanin kod kojega uz ekonomsku vezanost bitan element čini i emocionalna komponenta.

Iz analize odredaba Uredbe br. 650/2012 o nasljeđivanju kojima se uređuje nadležnost dade se zamijetiti još jedan značajni aspekt u pristupu europskog zakonodavca. Naime, Uredba koristi pojam „stranke“ koji je imanentan redovnom parničnom postupku, premda se dio pitanja nasljeđivanja u nacionalnim sustavima država članica rješava u izvanparničnoj proceduri. U smislu odredaba hrvatskog $\mathrm{ZN}$, gdje je ostavinski postupak predviđen kao izvanparnični postupak, a strankama se smatraju nasljednici i zapisovnici te druge osobe koje ostvaruju pravo iz ostavine, to se ne čini problematičnim (arg. ex čl. 175. u vezi s čl. 179.). Ipak, hrvatska procesnopravna teorija razlikuje redovni parnični postupak od izvanparničnog postupka u pogledu sudjelovanja stranaka upravo na način da u parničnom postupku sudjeluju dvije stranke, a u izvanparničnom postupku može sudjelovati jedna stranka, ali i više sudionika. Za usporedbu, u njemačkom pravu, odredbom $\S 8$ Nacrta izmjena postupaka u obiteljskim stvarima i stvarima izvanparnične sudbenosti ${ }^{35}$ (dalje: Nacrt FGG-Reformgesetz) ne definira se pojam „stranke“ nego pojam „sudionici“ postupka. Negativnom definicijom predviđeno

34 loc.cit.

35 Entwurf eines Gesetzes zur Reform des Verfahrens in Familiensachen und in den Angelegenheiten der freiwilligen Gerichtsbarkeit (FGG-Reformgesetz - FGG-RG), 16/6308, 07. 09. 2007. 
je da se neće smatrati „sudionikom“ osoba koja se u postupku treba saslušati ili dati neku informaciju ako ne ispunjava opće zakonske preduvjete za sudionike. ${ }^{36}$ Također, odredba $\S 345$ Zakona o postupku u obiteljskim stvarima i stvarima izvanparnične sudbenosti ${ }^{37}$ (dalje: FamFG), koja je smještena u dijelu općih odredaba kojima su regulirani postupci u pitanjima nasljeđivanja, umjesto pojma „stranke“ koristi pojam „sudionici“" u smislu odredbe § 7 Abs. 2. S. 1 istoga Zakona, uzimajući u obzir specifičnosti pitanja nasljeđivanja koja se, osim u parničnoj rješavaju i u izvanparničnoj proceduri. Imajući to u vidu, njemačka pravna teorija kritizira nekritičko preuzimanje pojmova iz Uredbe Brisel I procjenjujući kao neadekvatnu primjenu pojmova „stranke“ i „tuženi“. Problematičnost pa čak i neadekvatnost primijenjenog pristupa dade se uočiti kod odredaba poput one čl. 40. Uredbe br. 650/2012 o nasljeđivanju, ako se tumači u kontekstu primjene u odnosu na privremenog skrbnika ostavine kojega se ne može smatrati „tuženikom“ nego isključivo sudionikom postupka. ${ }^{38} \mathrm{U}$ svjetlu navedenog, utemeljenom se može ocijeniti primjedba njemačke pravne teorije da se u Uredbi br. 650/2012 o nasljeđivanju ne razlikuje regulacija parničnog i izvanparničnog postupka. ${ }^{39}$

\subsection{Nadležna tijela}

Kada je riječ o tijelima nadležnima za postupanje, Uredba br. 650/2012 o nasljeđivanju u pristupu vodi računa o tome da se u postupovnom smislu sustavi nasljeđivanja država članica razlikuju, što i podcrtava u Preambuli (20). Stoga, pojmu „sud“ pridaje široko značenje kako bi uz sudove pojam obuhvatio i tijela koja vrše sudske funkcije (javni bilježnici, registarski uredi) odnosno kod nasljeđivanja postupaju na temelju prenesenih ovlasti od suda (javni bilježnici, pravni stručnjaci). Iz pojma „sud“ isključena su ona tijela u državama članicama koja su sukladno nacionalnom pravu ovlaštena za pitanja nasljeđivanja, poput javnih bilježnika, ali ne vrše sudske funkcije (arg. ex Preambula 20). Prema odredbi čl. 3. st. 2. Uredbe br. 650/2012 o nasljeđivanju tijela država članica u postupanju trebala bi pružiti garancije prava na pravično suđenje, točnije kako je to predviđeno odredbom, garancije nepristranosti i prava svih stranaka na saslušanje. Protiv odluka koje takva tijela donesu trebalo bi biti moguće izjaviti pravni lijek (žalbu ili reviziju) te bi odluke trebale imati valjanost i učinak istovjetan odlukama pravosudnog tijela o istoj stvari (arg. ex čl. 3. st. 2. t. a i b). O tijelima i pravnim stručnjacima države članice će obavijestiti Komisiju na temelju čega će ona uspostaviti popis s relevantnim podatcima (arg. ex čl. 3. st. 2. u vezi s čl. 79. st. 1.).

Imajući u vidu praksu u državama članicama vezano uz postupanja u stvarima nasljeđivanja, Uredba br. 650/2012 o nasljeđivanju posebnu pažnju posvećuje

36 Usporedi Maganić i dr., op. cit., str. 79-80.

37 Gesetz über das Verfahren in Familiensachen und in den Angelegenheiten der freiwilligen Gerichtsbarkeit (FamFG), od 17. prosinca 2008 (BGB1. I S. 2586, 2587).

38 Usporedi Dutta, A., op. cit. str. 19.

39 Vidi tako Dutta, A., ibid., str. 10. Usporedi Adolphsen, J., op. cit., str. 308. 
postupanju javnih bilježnika. Tako se u Preambuli (21) pojašnjava da bi Uredba br. 650/2012 o nasljeđivanju trebala omogućiti svim javnim bilježnicima koji imaju ovlasti u nasljednim stvarima u državama članicama izvršavanje tih ovlasti. Konkretno, javni bilježnici u državi članici trebali bi biti vezani pravilima o nadležnosti ako u državi članici vrše sudsku funkciju, a njihove odluke trebale bi biti u optjecaju u skladu s odredbama o priznavanju, izvršivosti i izvršavanju odluka (arg. ex Preambula 22).

Budući da, kako je to već ranije spomenuto, uz općinski sud javni bilježnik kao povjerenik suda je tijelo nadležno za postupanje u ostavinskom postupku te poduzima sve radnje i donosi sve odluke osim onih za koje ZN propisuje drukčije, od toga se polazi i u Zakonu o provedbi Uredbe br. 650/2012 o nasljeđivanju te se u odnosu na postupanje javnog bilježnika kao sudskog povjerenika izravno upućuje na primjenu odredaba ZN (arg. ex čl. 11. st. 3.).

Ostavinski se postupak provodi kao izvanparnični postupak, a pritom odredbe Zakona o parničnom postupku ne primjenjuju se izravno, nego na odgovarajući način, odnosno na način da se vodi računa o specifičnostima toga postupka kao izvanparničnog postupka. Zakon o provedbi Uredbe br. 650/2012 o nasljeđivanju, uz to što izrijekom predviđa koja su to nadležna tijela za vođenje određenih postupaka, precizira način na koji se ima postupati u pojedinim postupcima.

Za vođenje postupka u povodu zahtjeva za priznanje odluke donesene u drugoj državi članici u RH bit će nadležan općinski sud (arg. ex čl. 4. st. 1. Zakon o provedbi Uredbe br. 650/2012 o nasljeđivanju). Premda odredba čl. 45. st. 1. predviđa da se zahtjev za proglašenje ovršnosti (izvršivosti) podnosi sudu ili nadležnom tijelu države članice izvršenja o kojima je ta država članica obavijestila Komisiju u skladu s čl. 78. Uredbe br. 650/2012 o nasljeđivanju, iz dikcije odredbe čl. 4. st. 2. Zakona o provedbi Uredbe br. 650/2012 o nasljeđivanju gdje je predviđeno da će o zahtjevu u smislu čl. 45. st. 1., čl. 60. st. 1. i čl. 61. st. 1. Uredbe br. 650/2012 o nasljeđivanju odlučivati općinski sud dade se zaključiti da je RH obavijestila Komisiju da je isključivo općinski sud (ne i nadležna tijela) ovlašten proglasiti ovršnost (izvršivost) odluka $\mathrm{i}$ javnih isprava donesenih odnosno sudskih nagodbi sklopljenih u drugoj državi članici.

Odredbom čl. 5. st. 1. Zakona o provedbi Uredbe br. 650/2012 o nasljeđivanju uređena je nadležnost tijela za izdavanje ovjere odluka, javnih isprava i sudskih nagodbi. Ovjeru za potrebe priznanja ili proglašenja ovršnosti (izvršivosti) odluke donesene u jednoj državi članici u drugoj državi članici kako to predviđa odredba čl. 46. st. 3. t. b Uredba br. 650/2012 o nasljeđivanju u RH izdaje općinski sud koji je odlučivao u prvom stupnju, odnosno javni bilježnik koji je donio odluku na koju se odnosi prijedlog za izdavanje ovjere. Kada je riječ o ovjeri javnih isprava sukladno odredbi čl. 59. st. 1. i čl. 60. st. 2. Uredbe br. 650/2012 o nasljeđivanju nadležan je sud, odnosno javni bilježnik koji je izdao javnu ispravu za koju se predlaže izdavanje ovjere. Za izdavanje ovjere sudske nagodbe iz čl. 61. st. 2. Uredbe br. 650/2012 o nasljeđivanju nadležan je sud pred kojim je sklopljena sudska nagodba.

Uz unificiranje pravila postupaka u stvarima nasljeđivanja, Uredba br. 650/2012 o nasljeđivanju uspostavlja europsku potvrdu o nasljeđivanju koja 
proizvodi učinke $\mathrm{u}$ državama članicama bez potrebe provođenja posebnog postupka. Njome se omogućuje nasljednicima, legatarima koji imaju izravna prava u nasljedstvu i izvršiteljima oporuka ili upraviteljima ostavinom koji se u drugoj državi članici moraju pozvati na svoj status ili izvršavati svoja prava kao nasljednici ili legatari i/ili svoje ovlasti kao izvršitelji oporuka ili upravitelji ostavinom da na temelju potvrde izdane na njihov zahtjev dokazuju svoj status ili pravo, pripadnost određene imovine koja čini dio ostavine nasljednicima ili legatarima te ovlasti za izvršavanje oporuke ili upravljanje ostavinom (arg. ex čl. 63. st. 1. i 2.). A contrario, od mogućnosti da podnesu zahtjev za izdavanje europske potvrde o nasljeđivanju isključeni su vjerovnici kojima bi ona mogla poslužiti za provođenje ovrhe nad imovinom ostavine. U njemačkoj doktrini još u vrijeme izrade konačnog teksta Uredbe br. 650/2012 o nasljeđivanju sugerirano je da bi predviđeno rješenje trebalo dopuniti, a pritom su kao primjer uzete odredbe $\S \S 792$ i 896 njemačkog Građanskog zakonika o procesnom redu ${ }^{40}$ (dalje: ZPO) sukladno kojima je vjerovnik ostavitelja radi provođenja ovrhe nad imovinom iz ostavine nadležnom tijelu ovlašten podnijeti zahtjev za izdavanje potvrde o nasljedstvu. ${ }^{41}$

Budući da su sukladno odredbi čl. 7. st. 2. Zakona o provedbi Uredbe br. 650/2012 o nasljeđivanju kao stranke u postupku povodom zahtjeva za izdavanje potvrde predviđene osobe navedene u čl. 63. st. 1. Uredbe (EU) br. 650/2012, iz čega slijedi da su i prema hrvatskom pravu od prava na podnošenje zahtjeva za izdavanje europske potvrde o nasljeđivanju isključeni vjerovnici, potrebno je preispitati ima li mjesta za proširenje kruga ovlaštenika na podnošenje zahtjeva za njezino izdavanje na način da se obuhvate i vjerovnici ostavitelja, kako to sugerira njemačka pravna teorija. Ako se pođe od toga da nasljednici, legatari koji imaju izravna prava u nasljedstvu i izvršitelji oporuka ili upravitelji ostavinom kao ovlaštenici na podnošenje zahtjeva za izdavanje europske potvrde o nasljeđivanju koriste Potvrdu kako bi dokazali određeno pravo (pravo na nasljedstvo, ovlasti za izvršavanje oporuke, upravljanje ostavinom) koje proizlazi iz njihova položaja u ostavinskom postupku, dvojbenim se čini isključenje vjerovnika od mogućnosti podnošenja zahtjeva za izdavanje europske potvrde o nasljeđivanju. Naime, prema shvaćanju hrvatske judikature „ostaviteljev vjerovnik, samo je sudionik $\mathrm{u}$ ostavinskom postupku, ali ne i stranka u ostavinskom postupku, premda je u njemu aktivno sudjelovao i to u povodu pravomoćno utvrđene novčane tražbine predlagatelja u odnosu prema ostavitelju. Naime, ostaviteljev vjerovnik (čl. 139. i 140. ZN), isto kao i izvršitelj oporuke (čl. 60. ZN), te skrbnik ostavine (čl. 128. ZN) i privremeni skrbnik ostavine (čl. 199. i 200. ZN), nemaju položaj stranke u ostavinskom postupku, budući da isti ne ostvaruju nikakvo pravo na ostavinu kao takvu jer ga niti nemaju, nego ostvaruju svoja prava i zahtjeve prema nasljednicima kao cjelini, koji su nastali u povodu pokretanja i vođenja ostavinskog postupka te sudjelovanja ovih osoba u nekim radnjama obavljenim u tijeku ostavinskog

40 Zivilprozessordnung od 5. prosinca 2005. (BGB1. I S. 3202; 2006 I S. 431; 2007 I S. 1781), posljednje izmjene čl. 3. od 11. ožujka 2016. (BGBl. I S. 396).

41 Usporedi Sturm, F. i Sturm G., op. cit., str. 333. 
postupka. Stoga, ovakvi sudionici u postupku su osobe različite od suda i stranaka, a koje u postupku ostvaruju neki svoj pravni interes sa zahtjevom da sud u njihovu korist, u povodu njihova sudjelovanja u postupku, donese neku određenu odluku. To bi bile u stvari tzv. treće posredno zainteresirane osobe kojima zbog postojanja nekog određenog interesa pripada pravo žalbe protiv onih odluka koje se na njih odnose. ${ }^{\text {“42 }}$ U svjetlu iznesenog shvaćanja, koje izjednačuje izvršitelje oporuke, privremene skrbnike ostavine i vjerovnike u pogledu svojstva u kojemu sudjeluju u ostavinskom postupku, nije posve jasno isključenje potonjih u mogućnosti podnošenja zahtjeva za izdavanje europske potvrde o nasljeđivanju.

Prema odredbi čl. 6. st. 1. Zakona o provedbi Uredbe br. 650/2012 o nasljeđivanju za izdavanje europske potvrde o nasljeđivanju nadležan je općinski sud ili javni bilježnik kao povjerenik suda. Pojedino će tijelo biti nadležno ako je pred njim u tijeku ili pravomoćno okončan ostavinski postupak. Pritom, za razliku od suda koji posjeduje izvorna ovlaštenja, ovlaštenje javnog bilježnika proizlazi iz povjerenog mu ovlaštenja za vođenje postupka i odlučivanje o zahtjevu za izdavanje potvrde suda (arg. ex čl. 6. st. 3. Zakona o provedbi Uredbe br. 650/2012 o nasljeđivanju).

\subsection{Postupci}

U analizi dijela odredaba Uredbe br. 650/2012 o nasljeđivanju kojima su regulirani postupci posebnu je pozornost potrebno posvetiti odredbama o novouvedenoj mogućnosti izdavanja europske potvrde o nasljeđivanju. Usprkos namjeri da se njezinim uvođenjem doprinese brzom, jednoobraznom, skladnom i učinkovitom rješavanju nasljeđivanja s prekograničnim elementom (arg. ex Preambula 67), podnošenje zahtjeva za izdavanje europske potvrde o nasljeđivanju predviđeno je kao mogućnost, a ne obveza stranaka. To jasno proizlazi iz Preambule (69) koja izjednačava europsku potvrdu o nasljeđivanju s drugim instrumentima predviđenima Uredbom, odnosno odlukom, javnom ispravom i sudskom nagodbom.

Budući da Uredba br. 650/2012 o nasljeđivanju upućuje na primjenu nacionalnih pravila u pogledu nadležnosti sudova i drugih tijela s nadležnošću u nasljednim stvarima, poput javnih bilježnika (arg. ex Preambula 70), sud odnosno javni bilježnik bit će ovlašteni za izdavanje Potvrde u hrvatskom pravnom sustavu (arg. ex čl. 6. st. 1. Zakona o provedbi Uredbe br. 650/2012 o nasljeđivanju). Strankama je podnošenja zahtjeva, a sudovima i javnim bilježnicima izdavanje Potvrde olakšano mogućnošću korištenja obrasca čije je uspostavljenje predviđeno u skladu sa savjetodavnim postupkom iz odredbe čl. 81. st. 2. Uredbe br. 650/2012 o nasljeđivanju (arg. ex čl. 65. st. 2. u vezi s čl. 67. st. 1. Uredbe br. 650/2012 o nasljeđivanju). Nakon primitka zahtjeva tijelo ga razmatra zajedno s dostavljenom dokumentacijom (izjave, isprave, dokaze). Uz obvezu obavještavanja stranaka o podnesenom zahtjevu sud odnosno javni bilježnik dužan je saslušati stranke, ako je

42 Vrhovni sud Republike Hrvatske, broj Gžzp 317/2008-2 od 15. rujna 2009. 
to potrebno za utvrđivanje elemenata koji se trebaju potvrditi, bilo koju uključenu osobu i bilo kojeg izvršitelja ili upravitelja i vrši javne objave radi davanje prilike drugim mogućim korisnicima za pozivanje na svoja prava (arg. ex čl. 66 . st. 4. Uredbe br. 650/2012 o nasljeđivanju). U hrvatskom pravu obavještavanje i pozivanje stranaka javnom objavom provodit će se sukladno odredbama ZN o pozivanju oglasom, a rok za javljanje sudu, odnosno javnom bilježniku je dva mjeseca od objave oglasa u javnom glasilu »Narodne novine« (arg. ex čl. 7. st. 2. Zakona o provedbi Uredbe br. 650/2012 o nasljeđivanju).

Ako su ispunjene pretpostavke za izdavanje Potvrde, općinski sud, odnosno javni bilježnik izdat će potvrdu na obrascu i dostavit će strankama ovjerenu presliku Potvrde. Pritom, izvornik ostaje kod općinskog suda ili javnih bilježnika. Specifičnim se čini ograničenje razdoblja u kojemu vrijedi ovjerena preslika Potvrde na šest mjeseci od njezinog izdavanja, nakon čega se može zatražiti produženje. Uz to, kao iznimka,predviđena mogućnost da općinski sud ili javni bilježnik odredi dulje razdoblje važenja (arg. ex čl. 70. st. 3.). To bi ograničenje trebalo poslužiti kao svojevrsna kontrola u primjeni Potvrde. ${ }^{43}$

Ako je potvrdu izdao javni bilježnik dopušten je prigovor o kojem odlučuje općinski sud u postupku u kojemu se primjenjuju odredbe čl. 185. do 187. ZN o prigovoru protiv rješenja o nasljeđivanju. Također, zahtjev, zajedno sa spisom predmeta, javni bilježnik dostavit će općinskom sudu radi odlučivanja, ako utvrdi da nisu ispunjene pretpostavke za izdavanje potvrde. Javni bilježnik dužan je pisano obrazložiti zašto smatra da nisu ispunjene pretpostavke za izdavanje potvrde te izvijestiti podnositelja zahtjeva da je predmet upućen sudu (arg. ex čl. 7. st. 2., 3., 4. Zakona o provedbi Uredbe br. 650/2012 o nasljeđivanju). Ako općinski sud odluči odbaciti ili odbiti zahtjev za izdavanje potvrde, rješenje o tome dostavit će se strankama (arg. ex čl. 7. st. 6. Zakona o provedbi Uredbe br. 650/2012 o nasljeđivanju).

Sukladno odredbi čl. 7. st. 7. Zakona o provedbi Uredbe br. 650/2012 o nasljeđivanju protiv Potvrde koju je izdao općinski sud, odnosno protiv rješenja općinskog suda kojim je odbacio ili odbio zahtjev za izdavanje Potvrde dopušteno je podnošenje žalbe. Županijski sud odlučivat će o žalbi uz primjenu odredaba čl. 188. i 189. ZN koje se odnose na postupak i odluke o žalbi protiv rješenja o nasljeđivanju.

Ostaje otvoreno može li općinski sud odnosno javni bilježnik ograničiti Potvrdu izdanu na temelju zahtjeva na imovinu unutar država članica na način kao što to može učiniti u postupku u kojem odlučuje o nasljeđivanju na zahtjev jedne od stranaka, ako se može očekivati da njegova odluka u pogledu tog dijela imovine neće biti priznata i, prema potrebi, proglašena izvršivom u trećoj državi (arg. ex čl. 12. u vezi s čl. 64. st. 1.). Doslovna interpretacija odredbe čl. 64. st. 1. Uredbe br. 650/2012 o nasljeđivanju sugerira da općinski sud odnosno javni bilježnik to ne bi

43 Usporedi Dutta, A., op. cit., str. 21. Isto tako Grubišić Đogić, N. Prekogranično pravo nasljeđivanja prema Uredbi broj 650/2012, Zagreb, Informator, br. 6370, str. 1-8., str. 7. 
bili ovlašteni učiniti pri izdavanju Potvrde, a na istovjetan je način o tome zaključila i njemačka pravna teorija. ${ }^{44}$

U praktičnom smislu nameće se pitanje kako će se razriješiti situacija ako se sudu istovremeno podnese javna isprava koju je sukladno pravilima nacionalnog prava izdalo tijelo u državi članici te Potvrda koju je izdalo tijelo u državi članici porijekla, a u ostalim državama članicama proizvodi istovjetan učinak, odnosno kojoj od isprava će sud dati prednost. Naime, Uredba br. 650/212 o nasljeđivanju uređuje izdavanje potvrde kao mogućnost, a ne obvezu pa u tom smislu niti ne propisuje da se prednost ima dati Potvrdi. Opravdano je za očekivati da će konačan odgovor na to pitanje dati CJEU, osobito ako se uzme u obzir podijeljenost stavova među pravnim teoretičarima i praktičarima, među kojima neki smatraju da bi svakako prednost imala Potvrda, prema drugima javna isprava tijela države članice, a neki čak smatraju da bi o tome koja bi isprava imala prednost trebalo prema okolnostima slučaja odlučiti tijelo pred kojim se postavilo pitanje autentičnosti navedenih isprava. ${ }^{45}$ Među iznesenim shvaćanjima najprihvatljivijim se ipak čini prijedlog da se primjena Potvrde, $u$ odnosu na javne isprave izdane $u$ skladu s nacionalnim pravom država članica, primjenjuju isključivo u slučajevima odlučivanja o pitanjima nasljeđivanja s prekograničnim elementom, budući da bi se tako izbjegle dvojbe o tome kojoj bi se od isprava trebalo dati prednost. ${ }^{46}$

\section{PREDMET C404/14 MATOUS̆KOVÁ V. REPUBLIKA ČE ̌̆KA}

S obzirom na to da je Uredba br. 650/2012 o nasljeđivanju među najnovijim europskim instrumentima iz područja pravosudne suradnje u građanskim stvarima te je u državama članicama u primjeni od 17. listopada 2015. godine, ne čudi da za sada CJEU još nije imao prilike razmatrati otvorena pitanja koja proizlaze iz tumačenja pojedinih odredaba Uredbe. Ipak, u kontekstu primjene Uredbe br. 650/2012 CJEU je značajnu odluku u povodu zahtjeva za prethodnu odluku donio u predmetu C404/14 Matoušková v. Republika Češka. U tom je predmetu CJEU postavljen zahtjev za prethodnu odluku u pogledu pitanja ,je li odluka suda kojom odobrava sporazum o nasljeđivanju skrbnik maloljetne osobe za njezin račun da bi on bio valjan, iz perspektive CJEU, mjera u smislu čl. 1. st. 1. t. (b) ili mjera u smislu čl. 1. st. 3. t. (f) Uredbe br. 2201/2003 [...]?““.

Kako bi kontekst u kojemu je CJEU donio odluku u povodu zahtjeva za prethodnu odluku bio jasniji, potrebno je ukratko prikazati činjenice u glavnome

44 Usporedi Dutta, A., op. cit., str. 21.

45 Stav da bi prednost trebalo dati Potvrdi zastupa se u francuskoj pravnoj teoriji. Vidi Lagarde, $\mathrm{P}$, Les principes de bases dunouveaurèglement européen sur les successions, RCDIP, br. $4 / 2012$, str. 72. U rumunjskoj pravnoj teoriji zastupa se protivan stav, tako Olaru I., Dreptul europeanal succesiunilor internaţionale, Ghid practic, (ed.), Notarom, 2014., str. 154. Hrvatski pravni stručnjaci shvaćanja su da bi odluku o tome ipak trebalo povjeriti tijelu pred kojim se pojavilo pitanje autentičnosti navedenih isprava. Tako Grubišić Đogić, N., loc. cit.

Tako Hess, B., Mariottini, C. i Camara, C., op. cit., str. 23. 
postupku. Ostavinski postupak M. Martinus, preminule 8. svibnja 2009. godine u Nizozemskoj pokrenut je pred Općinskim sudom u Brnu (Městský soud v Brně) dana 27. travnja 2010. godine. Javnom bilježniku M. Matouškovoj, bilo je povjereno izvršenje radnji u postupku u nasljednim stvarima u svojstvu sudskog povjerenika. U postupku je utvrđeno da je ostaviteljica bila češka državljanka, koja je u trenutku smrti imala boravište u Brnu u Češkoj Republici. Njezini nasljednici, suprug i njihovo dvoje maloljetne djece imali su boravište u Nizozemskoj. Djeci je u skladu s češkim pravom postavljen privremeni skrbnik radi zastupanja interesa u postupku. Dana 14. srpnja 2011. godine sklopljen je sporazum o raspodjeli nasljedstva među nasljednicima, a odlukom od 10. kolovoza 2011. godine Općinski sud u Brnu odredio je ukupnu vrijednost imovine ostaviteljice, iznos dugova i obračunsku vrijednost ostavine. Nove okolnosti u ostavinskom postupku nastupile su izjavom supruga ostaviteljice od 2. kolovoza 2012. godine da je ostaviteljica u trenutku smrti imala boravište Nizozemskoj, a da je u Češkoj Republici imala samo registrirano boravište koje u stvarnosti nije bilo tamo. Osim toga, izjavio je da je u Nizozemskoj već bio u tijeku ostavinski postupak o čemu je dostavio potvrdu s datumom od 14. ožujka 2011. godine. Nakon što je sud nadležan za skrbništvo, ne upuštajući se u meritum, vratio spis M. Matouškovoj koja mu ga je uputila, zbog toga što su malodobni potomci već dugo boravili izvan Češke Republike, pojasnivši da se ne može proglasiti nenadležnim kao i da ne može uputiti predmet Vrhovnom sudu (Nejvyššíjem soudu) radi utvrđivanja mjesno nadležnog suda, M. Matoušková se 10. srpnja 2013. godine izravno obratila Vrhovnom sudu zahtijevajući od njega da odredi koji je sud mjesno nadležan za odobravanje sporazuma o raspodjeli nasljedstva o kojemu je riječ u glavnom postupku. Vrhovni sud ocijenio je neophodnim da u svojoj odluci CJEU protumači ima li mjesta primjeni Uredbe br. 2201/2003 jer je odobrenje sporazuma o kojemu je riječ mjera namijenjena zaštiti interesa maloljetnika i može potpadati pod područje primjene te uredbe ili je opravdano kvalificirati ga kao mjeru koja se odnosi na nasljeđivanje u smislu Uredbe br. 650/2012 o nasljeđivanju te kao takva može biti isključena iz područja primjene Uredbe br. 2201/2003 na temelju njezina čl. 1. st. 3. točke (f).

Odobrenje sporazuma o raspodjeli nasljedstva mjera je donesena s obzirom na poslovnu sposobnost maloljetnika i s ciljem zaštite interesa djeteta te koja je, na temelju češkog prava, propisana za pravne radnje koje se odnose na upravljanje imovinom koja ne potpada pod tekuće upravljanje. Prema procjeni CJEU riječ je o mjeri koja se izravno odnosi na poslovnu sposobnost fizičke osobe (vidjeti analogijom presudu Schneider, C386/12, EU:C:2013:633, t. 26.) te po svojoj prirodi ulazi u okvir radnje čiji je cilj zadovoljiti potrebe zaštite i pružanja pomoći malodobnim potomcima. Budući da nezavisna odvjetnica u t. 41. svoga mišljenja tvrdi da poslovna sposobnost i povezana pitanja, primjerice pitanja postavljanja skrbnika malodobnim potomcima i nadzor izvršavanja njegovih radnji treba ocjenjivati prema vlastitim mjerilima, ne može se smatrati da je činjenica da se u okviru ostavinskog postupka zahtijeva odobrenje o kojemu je riječ u glavnom postupku odlučujuća za to da ta mjera potpada pod nasljedno pravo. Pretpostavka 
ishođenja odobrenja suca nadležnog za skrbništvo izravna je posljedica stanja i sposobnosti malodobnih potomaka te je mjera zaštite djeteta povezana $\mathrm{s}$ upravljanjem, čuvanjem ili raspolaganjem njegovom imovinom u okviru izvršavanja roditeljske odgovornosti u smislu članka 1. st. 1. t. (b) i st. 2. točke (e) Uredbe br. 2201/2003.

Iz tumačenja Uredbe br. 650/2012 o nasljeđivanju CJEU u prvom redu zaključuje da ona ratione temporis nije primjenjiva u glavnom postupku. Nadalje, za okolnosti postupka relevantnim je ocijenjeno da je donesena zbog toga da, u skladu s Preambulom (9), u nju budu uključeni svi građanskopravni aspekti nasljeđivanja zbog smrti, a istovremeno, sukladno odredbi čl. 1. st. 2. t. (b) iz njezina područja primjene isključena je poslovnu sposobnost fizičkih osoba. Uredba u biti čl. 23. st. 2. t. (c) uređuje samo posebne aspekte koji se odnose na sposobnost nasljeđivanja kao i sposobnost osobe koja raspolaže imovinom zbog smrti da ima takvu sposobnost, u skladu s čl. 26. st. 1. t. (a) Uredbe.

CJEU je prilikom tumačenja područja primjene Uredaba br. 2201/2003 i br. 650/2012 o nasljeđivanju uzeo u obzir vlastitu sudsku praksu u kojoj pokušava izbjeći sva preklapanja pravnih pravila koja one propisuju kao i sve pravne praznine (Nickel \& Goeldner Spedition, C157/13, EU:C:2014:2145, t. 21. kao i navedenu sudsku praksu).

U razmatranju upućenog zahtjeva CJEU je pošao i od okolnosti da je Vrhovni sud također pitao nije li interes djeteta ugrožen podjelom postupka donošenja odluka u području nasljeđivanja između dviju različitih država članica, s jedne strane države u kojoj je pokrenut ostavinski postupak i, s druge strane, države u kojoj je uobičajeno boravište djeteta, podjelom koja je predviđena čl. 8. st. 1. Uredbe br. 2201/2003. Ipak, uporište za donošenje odluke CJEU je pronašao u odredbi čl. 12. st. 3. Uredbe br. 2201/2003 prema kojoj su sudovi države članice nadležni za roditeljsku odgovornost u postupcima, osim onih iz st. 1. tog članka ako, s jedne strane, postoji bitna veza djeteta i te države članice, posebno zbog činjenice da jedan od nositelja roditeljske odgovornosti ima uobičajeno boravište u njoj ili da je dijete njezin državljanin $i, s$ druge strane, nadležnost sudova su izričito ili na neki drugi nedvosmisleni način prihvatile sve stranke u postupku u trenutku njegova pokretanja pred sudom, a to je i u interesu djeteta. U prilog tome ide $\mathrm{i}$ stav Komisije prema kojoj čl. 12. st. 3. Uredbe br. 2201/2003 može biti temelj za utvrđivanje nadležnosti suda pred kojim se vodi postupak u stvarima nasljeđivanja radi odobravanja sporazuma o raspodjeli nasljedstva premda taj sud nije u državi članici u kojoj dijete ima uobičajeno boravište, ako su ispunjene gore spomenute pretpostavke.

Stoga je CJEU zaključio da na postavljeno pitanje valja odgovoriti da Uredbu br. 2201/2003 treba tumačiti na način da je odobrenje sporazuma o raspodjeli nasljedstva koji za račun malodobnih potomaka sklopi skrbnik, mjera koja se odnosi na izvršavanje roditeljske odgovornosti u smislu članka 1. stavka 1. točke (b) te uredbe i koja stoga potpada pod njezino područje primjene, a ne mjera koja se odnosi na nasljeđivanje u smislu članka 1. stavka 3. točke (f) spomenute uredbe, isključena iz njezina područja primjene. 
Ova odluka ilustrira poteškoće koje se mogu pojaviti u razgraničenju prilikom primjene instrumenata kod kojih se pojmovi međusobno nadopunjuju, kao što je to slučaj kod Uredbe 2201/2003 i Uredbe br. 650/2012 o nasljeđivanju. Premda je podjednako, u odnosu na svaku od Uredbi postojao naočigled nedvojben argument koji je otklanjao mogućnost njezine primjene, kao što je nezavisna odvjetnica Kokott u svome mišljenju pokazala, prije donošenja krajnjeg zaključka potrebna je detaljnija analiza. Tako se u odnosu na primjenu Uredbe br. 650/2012 o nasljeđivanju dade opravdano zaključiti da u trenutku vođenja češkog postupka u pogledu kojega je postavljen zahtjev za prethodnu odluku ona nije bila $u$ primjeni, budući da se u državama članicama primjenjuje tek od 17. kolovoza 2015. godine. Podjednako, u odnosu na Uredbu 2201/2003 stoji primjedba da je iz područja njezine primjene odredbom čl. 1. st. 3. t. (f) izuzeto nasljeđivanje. No, kao što to nezavisna odvjetnica Kokott zaključuje, iako se Uredba br. 650/2012 o nasljeđivanju vremenski još ne može primijeniti na češki glavni postupak, ipak se prema njezinu materijalnom području primjene može izvesti zaključak o tome koji je opseg zakonodavac pridao kriteriju isključivanja ,nasljeđivanja “ u Uredbi br. 2201/2003. Istovremeno, iz materijalnog područja primjene Uredbe br. 650/2012 o nasljeđivanju, u skladu s njezinim čl. 1. st. 2. t. (b), izuzeta je ,„pravna sposobnost fizičkih osoba“, dakle upravo ona područja prava o kojima se radi u glavnom postupku u kojem je riječ o posebnom skrbništvu maloljetnika i sudskom odobrenju sporazuma koji je zaključio njihov posebni skrbnik, pa se ne može tumačiti na način da se protivi primjeni Uredbe 2201/2003 i restriktivnom tumačenju isključenosti „,nasljeđivanja“" u smislu čl. 1. st. 3. t. (f). ${ }^{47}$

\section{ZAKLJUČ AK}

U namjeri da se u okviru europskog pravosudnog prostora stvore preduvjeti za ostvarivanje prava osoba u kontekstu nasljeđivanja koje ima prekogranične implikacije, Uredbom br. 650/2012 o nasljeđivanju predviđena je harmonizacija postupovnih pravila odnosno pravila država članica o sukobu nadležnosti i sukobu zakona iz toga područja. Stoga, Uredba br. 650/2012 o nasljeđivanju donosi pravila o nadležnosti, mjerodavnom pravu, priznavanju ili, ako je to slučaj, prihvaćanju, izvršivosti i izvršavanju odluka, javnih isprava i sudskih nagodbi i o uspostavi Europske potvrde o nasljeđivanju. Važnu komponentu čini i novi, moderniji pristup Uredbe br. 650/2012 o nasljeđivanju uređenju pitanja nasljeđivanja s prekograničnim elementom, koji pak nije bio bez izazova. Njegovu okosnicu čini primjena uobičajenog boravišta kao jedinstvenog kriterija za određivanje nadležnosti suda i mjerodavnog prava za nasljeđivanja. No, predstavlja li uistinu novouvedeno rješenje, u usporedbi s tradicionalno primjenjivanim kriterijima državljanstva i domicila najpogodniji kriterij?

47 Mišljenje nezavisne odvjetnice Kokott, t. 38 do 45. 
U pravnoj literaturi u prilog primjeni kriterija uobičajenog boravišta ističe se da doprinosi uklanjanju prepreka slobodnom kretanju osoba koje se trenutačno susreću s poteškoćama u ostvarivanju svojih prava u kontekstu nasljeđivanja s prekograničnim elementom. Nadalje, za razliku od kriterija državljanstva koji naglašava vezanost osobe za određenu državu članicu, produbljujući time značaj suvereniteta država članica i primjene njezinog prava u odnosu na njezine državljane, kriterij uobičajenog boravišta svojom fleksibilnošću i neutralnošću odgovara percepciji državljana država članica kao ravnopravnih građana EU, u odnosu na koje se primjenjuje pravo država članica ujednačeno prema standardima EU. Ipak, kriterij uobičajenog boravišta, točnije način na koji je predviđen u Uredbi br. 650/2012 o nasljeđivanju očituje i određene manjkavosti.

Upravo okolnost da se određenje kriterija uobičajenog boravišta izbjegavalo u okviru pravnih instrumenata koji ga rabe, kako bi se izbjegla rigidnost te je tako njegova primjena ostala „otvorena“ u odnosu na veliki broj slučajeva, zaslužna je za to da se njegovo određenje iščitava iz pojedinačnih interpretacija CJEU, u odnosu na specifičnosti svakog pojedinog slučaja. No, to svakako ne pridonosi ujednačenosti u njegovoj primjeni niti pravnoj sigurnosti. Uz to, jača bojazni od forum shopping-a. U tom smislu, dvojbeno je mogu li u Preambuli (23) predviđene smjernice osigurati potrebnu „stabilnost“ kriterija uobičajenog boravišta, osobito ako se zna da se i njihovo porijeklo može vezati uz judikaturu CJEU (poput slučaja C-523/07 A). U svrhu funkcionalizacije odabranog kriterija stoga oportuno bi ipak bilo posegnuti za određenjem pojma uobičajenog boravišta.

U tom smislu, bilo bi potrebno pomiriti standarde judikature CJEU i smjernice iz Preambule (23) sa shvaćanjima kriterija uobičajenog boravišta u državama članicama. Hrvatska procesnopravna teorija uobičajeno boravište (résidence habituelle) definira kao mjesto za koje se iz okolnosti konkretnog slučaja može pretpostaviti da će se određeni subjekt u njemu duže vrijeme zadržavati. Za takve osobe područje trajnijeg boravišta pravno se izjednačuje s prebivalištem, pa je i sud na čijem području trajnije borave za njih (primarno elektivno) općemjesno nadležan. ${ }^{48}$

U usporedbi, pravna literatura za potrebe određivanja uobičajenog boravišta u postupcima u stvarima nasljeđivanja s međunarodnim elementom na deskriptivan, $\mathrm{i}$ ne pretjerano formalistički način pojašnjava da ,svaka osoba prije smrti mora imati uobičajeno boravište čak i ako u to vrijeme samo boravi, a nije riječ o trajnijem boravištu, na području na kojemu je umrla". ${ }^{49}$

Izazov iznalaženja definicije uobičajenog boravišta koja pruža dostatno prilagodljivosti potrebama osiguravanja slobodnog kretanja građana EU, poštuje volju osoba te cjelovito uvažava pojedinosti vezane uz odabir boravišta osobe (čak i okolnost da je osoba istovremeno vezana uz teritorij više država članica), tim je

48 Tako Triva, S. i Dika, M., op. cit., str. 273.

49 Hayton, D., Determination of the objectively applicable law governing succession to deceaseds' estates, DNotl, Les Succesions Internationales dans I'UE, 2004, str. 359-370., str. 365. 
veći, jer istovremeno treba težiti osiguranju ostvarenja načela pravne sigurnosti. Stoga, smjernice koje proizlaze iz komparativne analize određenja uobičajenog boravišta u državama članicama svakako trebale bi koristiti prilikom uobličavanja definicije koja bi odgovarala primjeni u postupcima u stvarima nasljeđivanja $\mathrm{s}$ međunarodnim elementom. Prema njima bi definicija trebala odražavati svojevrsnu mobilnost koncepta, intencije osobe o kojoj je riječ, komponentu "osobnog života“ umjesto „obiteljskog života“ osobe, okolnost da je osoba živjela u državi članici u kojoj se utvrđuje uobičajeno boravište osobe te određenu trajnost boravka osobe u državi članici.

Ipak, ne treba zanemariti okolnost da Uredba br. 650/2012 o nasljeđivanju ne ostavlja posve po strani kriterij državljanstva. Naime, njegova je primjena povezana uz autonomiju volje stranaka, konkretno pravo odabira prava mjerodavnog za nasljeđivanje, u prvom redu ostavitelja, ali i nasljednika, koja je naglašenu u tekstu Uredbe br. 650/2012 o nasljeđivanju. To treba pripisati specifičnostima uređenja nasljeđivanja, kod kojega se pri raspodjeli imovine ostavitelja respektira njegovo raspolaganje nasljedstvom za života, zbog čega je opravdano omogućiti ostavitelju i da učini izbor u pogledu prava koje će se primijeniti za uređenje njegovog nasljeđivanja. Uz to, za razliku od kriterija uobičajenog boravišta, kriterij državljanstva lako je primjenjiv te znatno postojaniji kriterij, budući da je i način na koji se utvrđuje u državama članicama prilično ujednačen.

Određene zamjerke mogu se uputiti i u odnosu na terminološke nepreciznosti u okviru Uredbe br. 650/2012 o nasljeđivanju. One se mogu pripisati okolnosti da se nije posvetila osobita pažnja nužnom razlikovanju pravila postupaka koji se radi rješavanja pitanja nasljeđivanja provode u parničnoj odnosno izvanparničnoj proceduri. Poželjno bi tako bilo uz pojam „stranke“ koji je imanentan parničnoj proceduri uvesti i pojam ,sudionika“, koji bolje odgovara izvanparničnoj proceduri, u kojoj se provodi i ostavinski postupak. Nadalje, jasnoći odredaba ne pridonosi ni usporedna primjena pojma ,sud“ te pojma „tijelo“, osobito ako se uzme u obzir da prema određenju kojega donosi Uredba br. 650/2012 o nasljeđivanju u čl. 3. st. 2. pojam „sud“ označava sva pravosudna tijela i sva ostala tijela koja postupaju u skladu s prenesenim ovlastima u postupcima u smislu Uredbe.

Konačno, budući da se ideja europske potvrde o nasljeđivanju smatra jednim od najznačajnijih priloga Uredbe br. 650/2012 o nasljeđivanju olakšavanju rješavanja nasljeđivanja s prekograničnim elementom, okolnost da je njezina primjena opcijska može se tumačiti dvojako. Može se shvatiti na način da podcrtava autonomiju volje stranaka, koja je izražena u Uredbi br. 650/2012 o nasljeđivanju. No, pritom treba imati na umu da prepuštanje na izbor osobama ovlaštenima sukladno odredbi čl. 63. st. 1. Uredbe br. 650/2012 o nasljeđivanju da odluče o podnošenju zahtjeva za izdavanje Potvrde može imati pozitivne, ali i negativne reperkusije na razinu njezine primjenjivosti u praksi. Istovremeno, nepropisivanju obveze korištenja Potvrde može se pripisati i drugo značenje. Može se tumačiti kao nepoklanjanje dostatnog povjerenja europskog zakonodavca u spremnost stranaka i država članica da se u prekograničnom pravnom prometu vezano uz pitanja nasljeđivanja služe europskom potvrdom o nasljeđivanju. 
U odnosu na redakciju odredaba o europskoj potvrdi o nasljeđivanju treba spomenuti izostavljanje vjerovnika iz kruga osoba koje su ovlaštenici na podnošenje zahtjeva za izdavanje Potvrde. Argumenti koje je ponudila njemačka pravna teorija kao i analiza stava iznesenog u hrvatskoj judikaturi čine se dostatno uvjerljivima kako bi se otvorilo pitanje opravdanosti neuvrštavanja vjerovnika u krug ovlaštenika na podnošenje europske potvrde o nasljeđivanju.

Unatoč uočenim nesavršenostima, Uredbu br. 650/2012 o nasljeđivanju treba cijeniti kao instrument koji će značajno unaprijediti rješavanje pitanja nasljeđivanja s prekograničnim elementom. Za očekivati je da će se, s obzirom na doprinos koji se očekuje da će imati u unaprjeđenju pravosudne suradnje u građanskim stvarima u EU na području nasljeđivanja, sve prepreke njezinoj učinkovitoj primjeni pokušati otkloniti, dijelom već u judikaturi CJEU, a dijelom i u budućim intervencijama europskog zakonodavca. 


\section{Summary}

\section{JURISDICTION, COMPETENT JUDICIAL AUTHORITIES AND PROCEEDINGS UNDER REGULATION (EU) NO 650/2012 ON SUCCESSION}

Novelties in the field of matters of succession brought by implementation of Regulation (EU) No 650/2012 of the European Parliament and of the Council of 4 July 2012 on jurisdiction, applicable law, recognition and enforcement of decisions and acceptance and enforcement of authentic instruments in matters of succession and on the creation of a European Certificate of Succession are disscused in the paper. Especial emphasis is on jurisdiction, competent judicial authority and proceedings under Regulation on succession. In this sense, in the first part of the paper detailed analysis of provisions of Commission Implementing Regulation (EU) No 1329/2014 of 9 December 2014 establishing the Forms referred to in Regulation (EU) No 650/2012 of the European Parliament and of the Council on jurisdiction, applicable law, recognition and enforcement of decisions and acceptance and enforcement of authentic instruments in matters of succession and on the creation of a European Certificate of Succession and provisions of Croatian Law on implementation of Regulation (EU) No 650/2012 of the European Parliament and of the Council on jurisdiction, applicable law, recognition and enforcement of decisions and acceptance and enforcement of authentic instruments in matters of succession and on the creation of a European Certificate of Succession is provided. In the second part of the paper case C404/14 Matoušková v. Republic of Czech is presented and difficulties in determining whether the case at issue falls within the scope of Regulation (EC) No 2201/2003 or Regulation No 650/2012 on succession which could occur in matters of succession with cross-border implications are reffered to.

Key words: matters of succession, cross-border implications, Regulation on succession, notary public, court proceedings, case C-404/14. 


\section{Zusammenfassung}

\section{ZUSTÄNDIGKEIT, ZUSTÄNDIGKEITSBEHÖRDEN UND VERFAHREN GEMÄß VERORDNUNG (EU) NR. 650/2012 ÜBER ERBSACHEN}

Diese Arbeit stellt Neuigkeiten im Bereich des Erbrechts im Lichte der Verordnung Nr. 650/2012 des Europäischen Parlaments und des Rates vom 4 Juli 2012 über die Zuständigkeit, das anzuwendende Recht, die Anerkennung und Vollstreckung von Entscheidungen und die Annahme und Vollstreckung öffentlicher Urkunden in Erbsachen sowie zur Einführung eines Europäischen Nachlasszeugnisses dar. Bestimmungen zur Zuständigkeit, zuständigen Behörden und Verfahren, welche nach der Erbrechtsverordnung durchgeführt werden, sind besonders unter die Lupe genommen. In diesem Sinne analysiert der erste Teil der Arbeit Bestimmungen, die in Bezug auf die Anwendung der Verordnung Nr. 650/2012, die Durchführungsverordnung der Kommission Nr. 1329/2014 vom 9 Dezember 2014 und zur Festlegung der Formblätter nach Maßgabe der Verordnung Nr. 650/2012 des Europäischen Parlaments und des Rates über die Zuständigkeit, das anzuwendende Recht, die Anerkennung und Vollstreckung von Entscheidungen und die Annahme und Vollstreckung öffentlicher Urkunden in Erbsachen sowie zur Einführung eines Europäischen Nachlasszeugnisses verabschieden wurden, wie auch Bestimmungen des kroatischen Gesetzes über die Durchführung der Verordnung Nr. 650/2012. Im zweiten Teil folgt eine Analyse der Rechtssache C-404/14 Matoušková v. Republika Češka, die Schwierigkeiten einer Abgrenzung des Anwendungbereichs der Verordnung 2201/2003 von der Verordnung 650/2012 über Erbsachen, welche in einigen Erbsachen mit internationalen Elementen auftauchen können, hervorhebt.

Schlüsselwörter: Vererben, internationales Element, Erbrechtsverordnung, Notar, Verfahren vor Gericht, Rechtssache C-404/14. 


\section{Riassunto}

\section{COMPETENZA, ORGANI COMPETENTI E PROCEDIMENTI IN FORZA DEL REGOLAMENTO (UE) N. 650/2012 IN MATERIA DI SUCCESSIONI}

Nel lavoro si espongono le novità che in materia di successioni comporta l'applicazione del Regolamento n. 650/2012 del Parlamento europeo e del Consiglio del 4 luglio 2012 sulla competenza, sul diritto applicabile, sul riconoscimento e sull'esecuzione delle decisioni e sull'accettazione ed esecuzione dei documenti pubblici nelle questioni successorie, come pure sulla creazione del certificato successorio europeo. Particolare attenzione viene prestata alle disposizioni con le quali si regola la competenza, gli organi che conducono il procedimento, così come i procedimenti che verranno intrapresi in applicazione del Regolamento $\mathrm{n}$. $650 / 2012$ sulla successione. In tale senso nella prima parte del lavoro si analizzano dettagliatamente sia le disposizioni, che con riferimento all'applicazione del Regolamento n. 650/2012 sulla successione, vengono emanate dal Regolamento di esecuzione (UE) n. 1329/2014 della Commissione del 9 dicembre 2014 che istituisce i moduli di cui al regolamento (UE) n. 650/2012 del Parlamento europeo e del Consiglio relativo alla competenza, alla legge applicabile, al riconoscimento e all'esecuzione delle decisioni e all'accettazione e all'esecuzione degli atti pubblici in materia di successioni e alla creazione di un certificato successorio europeo, sia le disposizioni della legge croata di attuazione del Regolamento n. 650/2012 sulla successione. Nella seconda parte del lavoro si disamina il caso C404/14 Matoušková contro Repubblica Ceca e si rilevano le difficoltà di distinzione tra il campo di applicazione del Regolamento (CE) n. 2201/2003 e quello del Regolamento n. 650/2012 in materia di successione; difficoltà che potrebbero presentarsi in singoli casi aventi carattere di internazionalità.

Parole chiave: successione, carattere di internazionalità, Regolamento in materia di successioni, notaio, procedimento giudiziario, caso C-404/14. 